\title{
Principles and policies: once more
}

\section{Tuori, Kaarlo}

Edward Elgar

2019-08-30

Tuori , K 2019 , Principles and policies: once more . in M La Torre , L Niglia \& M Susi (eds), The Quest for Rights : Ideal and Normative Dimensions . Edward Elgar, Cheltenham , pp. 215-23 . https://doi.org/10.4337/9781788971775.00017

http://hdl.handle.net/10138/310635

https://doi.org/10.4337/9781788971775.00017

unspecified

acceptedVersion

Downloaded from Helda, University of Helsinki institutional repository.

This is an electronic reprint of the original article.

This reprint may differ from the original in pagination and typographic detail.

Please cite the original version. 
This is a draft chapter. The final version is available in The Quest for Rights: Ideal and Normative Dimensions edited by M. La Torre, L. Niglia, \& M.Susi, published in 2019, Edward Elgar Publishing Ltd http://dx.doi.org/10.4337/9781788971775

The material cannot be used for any other purpose without further permission of the publisher, and is for private use only. 
Kaarlo Tuori

\section{Principles and policies: once more}

Several decades have already elapsed since Ronald Dworkin and Robert Alexy published their seminal writings on rules, principles and policies. They were not the first legal theorists to use these terms, but it is largely to their credit that the terms have become commonplaces in legal literature. Can anything new be said on this topic? Although 'rules', 'principles' and 'policies' are widely accepted as almost self-evident starting-points in legal scholarship, much confusion prevails over their significance. In particular 'legal principle' is a polysemous term, and quasi-problems easily arise if a particular conceptual sense is transferred to a context where it does not fit.

'Legal principle' is used both as a legal theoretical concept, claiming relevance across the boundaries of legal orders, and as a doctrinal concept, related to a distinct legal order. In EU law, for instance, 'general principle' is a doctrinal concept whose significance can only be grasped by examining the distinct sources of this legal order, primarily the jurisprudence of the ECJ. The relevance of legal theoretical debates for such a doctrinal inquiry is limited; rather, a straightforward introduction of legal theoretical insights can cause unnecessary bewilderment and lead scholars to non-problems.

In the following, my focus will be on the legal theoretical debate. However, in the final part of the paper I shall also present some observations concerning the general principles of EU law. I shall start by distinguishing between different connotations of 'legal principle' as a legal theoretical concept. Then I shall discuss differences in the approaches of Dworkin and Alexy and defend Dworkin's view of the relevance of separating principles from policies; a view also attacked by the rather strange bedfellows of CLS scholars and Richard Posner, the main protagonist of the Law and Economics school. I shall try to demonstrate that the distinction is important not only for examining judicial decision-making or for understanding how the law can defend itself against excessive instrumentalization. It is also important for perceiving the particularity of EU law as a policy-oriented legal order; a distinctive feature which forms a backdrop to EU law's conflicts with the more principle-oriented national legal regimes of Member States. 


\section{Varieties of legal principles}

Legal theoretical debate on legal principles seems to be riddled with mysteries. An author may treat legal principles as norms applicable to cases before courts; as a type of norms alongside with rules. However, the same author may also characterize principles as sources of law. But if legal principles are legal norms, which must find support in legal sources, how can they themselves be considered as such sources? The seeming mystery evaporates if we perceive that legal principles as legal norms are not exactly the same thing as legal principles taken as sources of law. Thus, the norm and the source qualities of legal principles do not necessarily exclude each other.

Dworkin and Alexy examined legal principles primarily as directly applicable legal norms, distinct from legal rules. ${ }^{1}$ Still, this is only one of the senses of 'legal principle'. The following list indicates the plethora of meanings:

- legal principles as norms applicable in legal decision-making (decision principles),

- legal principles as arguments employed in interpreting written sources of law, such as statutes and other regulations (interpretation principles),

- legal principles as summaries of the normative contents of a branch of law or the legal order as a whole (general legal principles),

- legal principles as legal sources supporting legal norms (source principles), and

- legal principles as normative premises for legislative solutions (legislative background principles).

If we in general can speak of a basic meaning of 'legal principle', my candidate would be that of general legal principles. Together with legal concepts and theories, general legal principles constitute a major element in the doctrinal infrastructure of distinct branches of law; what in German are called allgemeine Lehren and which is crucial for disciplinary identity. Such identity-building general legal principles include pacta sunt servanda in contract law; nulla poena sine lege in penal law; the detournement du pouvoir principles in administrative law; and democracy, separation of powers and proportionality in constitutional law. When emergent fields of law - say, communication law, information law or medical law - try to assert their distinctness, they point to putative general legal principles which are supposed to create coherence in concrete normative material.

\footnotetext{
${ }^{1}$ See especially Ronald Dworkin, Taking Rights Seriously (Duckworth 1978); Robert Alexy, A Theory of Constitutional Rights (Julien Roberts tr, OUP 2010).
} 
In order to facilitate grasping the role of different types of principles, as well as their interplay, law should be understood as a multi-layered normative phenomenon. Law as a normative legal order does not consist merely of explicit, discursively formulated norms, such as they appear, say, in statutes, other regulations and precedents. The surface level of explicit norms is underpinned by subsurface legal cultural layers, which both facilitate and restrict what can appear on the surface. Legal culture, in particular the expert culture of legal professionals, forms an integral part of the legal order. Legal culture, consisting of general legal principles, concepts and methodologies, informs the legal Vorverständnis through which legal professionals approach their tasks, and interpret and apply surface-level law. In legal practices, general legal principles mostly function through tacit, practical, knowledge. Only in hard cases does the need arise to articulate these principles and to specify the significance of, say, pacta sunt servanda or nulla poena sine lege, for the case at hand.

Decision principles and general legal principles have different domiciles in the multi-layered structure of legal order: decision principles are surface-level norms, while general legal principles are inhabitants of the sub-surface legal cultural layers. However, it is important to note that general legal principles, too, receive discursive expressions in surface-level normative material, such as court decisions in hard cases or scholarly writings articulating and elaborating on the doctrinal infrastructure of various fields of law, and even statutory provisions. In a hard case before a court or in a recapitulation of the doctrinal infrastructure of a legal order or a distinct branch of law, general legal principles could not even be identified without such manifestations in surface-level legal material. As Dworkin emphasizes, decision principles as legal norms need institutional support support in institutional legal sources - which distinguishes them from merely moral principles.

The notion of general legal principles has been subjected to severe criticism by analyticallyoriented scholars, such as the Finnish legal theorists Kaarle Makkonen and Aulis Aarnio. Their critique is based on a critique of legal inductivism, premised on the assumption that general legal principles are inferred through induction starting individual surface-level norms expressly enshrined in discursively formulated legal material. ${ }^{2}$ According to the view of the law's functioning I have tried to elaborate, general legal principles, in line with the conceptual and methodological elements of legal culture, originate in individual acts on the surface level of law; they result from a process of

\footnotetext{
${ }^{2}$ Kaarle Makkonen, Zur Theorie der juristischen Entscheidung (Turun yliopisto 1965) 195; Aulis Aarnio, Denkweisen der Rechtswissenschaft (Springer. 1979) 202.
} 
sedimentation starting from particular legislative, judicial and scholarly acts. ${ }^{3}$ Furthermore, general legal principles, such as they articulated by scholarly writings or courts' reasoning, must be inferred from the traces they have left on the law's surface. Yet this is something else than legal induction, defined in terms of inductive logic. At issue is perception of the normative point of the field of law in question; the point which brings coherence to the often scattered and fragmented surface-level normative material. I would argue that the intellectual operation at play in recognizing general legal principles is closer to the Anschauung which, according to the German historical school, is needed for the comprehension of organic normative wholes than to inductive logic. ${ }^{4}$

In recent decades, the discussion has focused on the role principles play in legal decisionmaking, i.e. as decision principles. In the view propounded by Dworkin and Alexy, legal rules adhere to an either-or logic: they are either applied or not, and if two rules stand in contradiction, only one of them can be valid and applicable. By contrast, legal principles follow a both-and logic. Conflict between two principles is resolved through weighing, so that neither of them loses its validity or applicability. The losing principle is also applied, but only within limits set by the weightier principle. In its systematizing and coherence-creating task, doctrinal research (legal dogmatics) not only identifies general legal principles but also puts forth proposals for their prima facie order of preference. Yet ultimately, conflicts between decision principles must be resolved case-by-case, in the light of the particular facts of the case at hand.

Without going deeper into the rules-and-principles debate, let me only raise one important point. Accepting Dworkin and Alexy's largely similar defining features of rules and principles proposed, the tricky question remains, how, then, can we tell whether a particular norm is of rule or principle quality. This is a key question in, for instance, human rights and fundamental rights law; in determining, first, which rights are absolute rights which cannot be derogated from during a state of emergency and on which limitations are not allowed; and secondly, what constitutes the inviolable core of rights where limitations are not permitted, either. Norms which define absolute rights and the inviolable core of other rights are rules by nature, while norms which define rights in the area where limitations are accepted are principles. ${ }^{5}$ If the norm has been expressed in legislation, the wording of the provision may provide a sufficient clue to its character. However, this is not always the case, but

\footnotetext{
${ }^{3}$ I have presented my view of law as consisting of a multi-layered normative legal order and specialized socio-legal practices, such as law-making, adjudication and legal scholarship, in Kaarlo Tuori, Critical Legal Positivism (Ashgate 2002) and Voluntas and Ratio (Ashgate 2011).

${ }^{4}$ See Tuori (2011),(n 3), 89.

${ }^{5}$ See Alexy, (n 1).
} 
often enough determining a norm's character requires other than linguistic arguments. In fundamental rights law, delineating the inviolable core of a right where the norm is of a rule character and the surrounding periphery where limitations are allowed and the norm is of a principle character always presupposes other than linguistic arguments: the same provision expresses both the rule and the principle.

Decision principles form part of the normative basis from which judges derive the decision norm for the case before them - the major premise of the judicial syllogism. In their guise of source and interpretation principles, principles accomplish important tasks even in the stages preceding formation of a decision norm. General legal principles, sedimented into the law's sub-surface layers, may provide source support for surface-level norms, which, in turn, may be either rules or principles in character. Legal principles' peculiar wavering between the surface and sub-surface levels manifests the recursive nature of the law. As legal principles result from a process of sedimentation originating from discursively formulated legal material, they depend on events on the surface level; on legal speech acts. But the demand for institutional support extends to legal-cultural principles too; now it manifests the relation of sedimentation, which confers on principles their legal nature.

Legal principles function not only as distinct legal sources on their own but as arguments in interpreting other sources as well. Interpretation principles are resorted to in order to warrant the construction of a norm proposition from written sources of law. One and the same principle may in some cases function as a decision principle and in others as an interpretation principle, guiding interpretation of statutory provisions. Such a dual character is typical of fundamental rights principles. They are legal norms obliging the courts and can function as decision principles, especially in the absence of other, complementary legislation. In general, though, courts have recourse to fundamental rights principles not as decision principles but as interpretation principles. In some legal systems, courts may even be legally obliged to do so. The New Zealand Bill of Rights of 1990 and the UK Human Rights Act 1998 include explicit provisions on such an interpretive duty.

\section{Dworkin vs Alexy}


Dworkin and Alexy's analyses of rules and principles are often lumped together. Indeed, they have important similarities, primarily, in the emphasis on the all-or-nothing application of rules and the necessity of weighing-and-balancing of principles. Yet significant differences exist as well.

In addition to rules and principles, Dworkin introduces another, complementary, distinction, which is of equal, if not even greater importance, for his argument. Principles in the broad sense of the term may be of two kinds: principles in the strict sense and policies. Policies are standards which determine ends concerning the economic, political or social state of the community. By contrast, principles in the strict sense express moral requirements, such as the demand for justice, and justify individual rights: "Arguments from principle are arguments which are supposed to justify a right; arguments from policy are arguments which are supposed to justify some collective end. Principles are propositions describing rights; policies are propositions describing ends." 6 The goods protected by rights are distributive in nature, whereas policies concern non-distributive collective goods.

Alexy has conceded that distributive rights and non-distributive collective goods are conceptually distinct, and he also has analysed possible relations between them. Collective goods and individual rights may, for example, be connected by a relation of justification: collective goods may justify individual rights and individual rights, in turn, collective goods. Still, Alexy does not see any need for complementing the division into rules and principles with an additional analytical distinction between principles and policies; he argues that both principles and policies, as defined by Dworkin, behave in the same way in legal decision-making. ${ }^{7}$ Alexy's downplaying the separation of principles from policies can be seen as a consequence of his definition of principles as commands of optimisation: if even principles in Dworkin's strict sense are characterized by scale-like, gradual realization, they indeed behave in the same way as policies aiming at collective goods.

However, Dworkin's and Alexy's differing views on the importance of distinguishing between principles and policies also reflect different views of legal scholarship. Alexy wants to keep the analytical and normative dimensions of legal scholarship strictly apart. For him, distinctions between different types of norms are analytical in nature; they do not imply any normative position in the interpretation or application of positive law, say, the fundamental rights provisions. ${ }^{8}$ By contrast, the very title of his breakthrough-work, Taking Rights Seriously, hints at the normative importance of the distinction between principles and policies: taking-rights-seriously is to let principles justifying and protecting individual rights trump in hard cases policies related to common

\footnotetext{
${ }^{6}$ Dworkin, ,(n 1), 22

${ }^{7}$ Robert Alexy, 'Individuelle Rechte und kollektive Güter', in Robert Alexy, Recht, Vernunft, Diskurs (Suhrkamp 1995), 232.

${ }^{8}$ See Alexy's presentation of the analytical, empirical and normative dimensions of legal scholarship in Alexy,(n 1), 22.
} 
goods. Dworkin does not see much point in making analytical distinctions independently of normative concerns. For him, the purpose of examining diverse categories of norms is not merely to increase the analytical clarity of normative argumentation and to raise the level of its rationality; distinctions between different types of norms are part and parcel of normative argumentation. The very idea of a distinction between analytic, empirical and normative dimensions of legal scholarship, a distinction cherished by Alexy, is foreign to Dworkin's approach. Although Dworkin introduces his classifications from the perspective of the judges, his primary normative concern is not with legal decision-making as such but with the law as a whole: as a full-blooded philosophical and political liberal, he is worried about the threat that the increasing policy-orientation of legislation - or, to put it in another way, the growing instrumentalization of law - poses to individual rights. Dworkin needs the distinction between principles and policies in order to be able to conceptualize the menace created by instrumentalist legal regulation and to explicate how the courts should try to fend it off. In respect of his main normative point, the first distinction, that between rules and principles, is of a merely preparatory nature; what really matters for his argument is the second distinction, i.e. that between principles and policies.

Although taken in the analytical dimension, Alexy's decision to discard the difference between principles and policies has obvious normative-doctrinal implications for fundamental rights. In German debates, he has been criticised for locating standards related to individual rights and collective goods, respectively, at the same level and, thus, according them equal initial argumentative weight in constitutional reasoning. According to Ingeborg Maus "this approach ... jeopardizes freedom when common goods can also be regarded as principles. ... constitutional guarantees of freedom compete with principles which are opposite not only in terms of their content, but also in terms of their entire structure, such as the efficiency of criminal justice, the 'efficiency of the Bundeswehr' or the 'efficiency of national defence' fundamental rights". 9

I am inclined to agree with Dworkin and Alexy's German critics on the importance of distinguishing between principles and policies. If, in constitutional interpretation, policies, aiming at collective goods, are equated with and given equal argumentative weight as principles, justifying individual rights, the power restricting edge of constitution would be blunted. The constitution of a democratic Rechtsstaat (constitutional democracy) would be in danger of losing one of its two legs. As Dworkin has shown, the distinction is also needed to provide constitutional democracy with doctrinal means to ward off excessive instrumentalization of law; i.e. for purposes of the self-defence of a constitutional democracy and its legal system.

\footnotetext{
${ }^{9}$ Ingeborg Maus, 'Die Trennung von Recht und Moral als Begrenzung des Rechts‘, (1989) 20 Rechtstheorie $191,197$.
} 
Dworkin developed the distinction between principles and policies with regard to decision principles. However, it can also be applied to other varieties of principles, discussed above; say, general legal principles or legislative background principles. In a contemporary state legal order, the general legal principles of distinct fields of law - private law, criminal law, procedural law, administrative law, constitutional law etc. - or the legal order as a whole are closer to morals-related principles than to policies. By contrast, in contemporary society legislative background principles tend, more often than not, to be policy- rather than principle-like. I have already argued that general legal principles mostly function in an unconscious way, through the practical knowledge - or, to use another vocabulary, Vorverständnis - of legal professionals. General legal principles play a key role in the maintenance of the law's relation to morals and in the protection of the law's legal cultural foundations in the face of instrumental legislation; or, as I have put it, in the self-defence of law.

\section{Radical critics}

Alexy does not negate the possibility of distinguishing between principles and policies; he just downplays its significance. He ignores the normative consequences which both adopting and rejecting the distinction entail. By contrast, more radical critics have challenged the very foundations of the distinction. In this criticism, CLS scholars shake hands with Richard Posner, a leading figure of the Law and Economics school, who has written of principles as rhetorically embellished policies. ${ }^{10}$ Their common position testifies to their common intellectual roots in American Legal Realism. Both CLS scholars and Posner argue that principles can be reduced to policies and that even the very distinction between principles and policies is policy-based. They both attack Dworkin for "rhetoric of rights" and detect underlying this rhetoric, too, policy considerations. Let us try to assess the arguments allegedly proving the collapse of principles into policies.

The first argument is familiar from debates between philosophical communitarians and liberals: the collective good is supposed to enjoy primacy over individual rights, allegedly based on principles. Correspondingly, Dworkin's principles are in fact grounded in policies. Thus, freedom of expression is based on a certain collective good; it purports "to support the collective system of political decision-making and public information that prevails in society". ${ }^{11} \mathrm{I}$ am inclined to accept this argument, but only in part. Fundamental rights and their underpinning principles are culturally possible only in a society whose strong values involve respect for these principles. Yet to concede this is not the same as to say that Dworkin's principles can be reduced to policies. The strong values,

\footnotetext{
${ }^{10}$ Richard Posner, 'How to skip the constitution', an exchange. (2007) 54 New York Review of Books (1), 63.

${ }^{11}$ Martti Koskenniemi 1999, 'The effect of rights on political culture' in Philip Alston (ed.), The EU and Human Rights (OUP 1999) 99, 105.
} 
as analyzed by Charles Taylor, ${ }^{12}$ do not equal the utilitarian, interest-based goals to which Dworkin and his critics allude with the notion of policy.

Another argument treats the vocabulary of fundamental rights and principles merely as a rhetorical choice by which judges or scholars pursue specific strategic policy goals, engaging in a politics of description, a strategically determined re-organization of the normative field. The cherished example is the fundamental rights dimension of EU law, suddenly "found" by the European Court of Justice. With its fundamental rights rhetoric, the Court attempted - so the CLS argument goes - to meet the challenge posed by the constitutional courts of some Member States and to safeguard its monopoly on the interpretation of EU law. ${ }^{13}$ Here, as usual, the CLS critics focus on the perlocutionary aspect of legal speech acts: their strategic aims and extra-discursive consequences. Legal speech acts do possess this dimension and therefore can be examined as acting out a strategic power game between legal actors or institutions. Nevertheless, this does not impede us from taking seriously the substantive validity claims of speech acts: arguments invoking fundamental rights or other principles can be assessed independently from their conceivable perlocutionary policy goals. The same holds for proposals by legal scholars for coherence-creating doctrines, involving a prima facie ordering of principles. In order to prove that principles are subordinate to policies or that the former are reducible to the latter, it is not enough to show that it is possible to approach judicial controversies or scholarly debates as a strategic contest over the power of stating the law. A policy analysis from a perlocutionary perspective does not cancel out an appraisal the substantive validity claims of principle arguments.

Dworkin's critics are also prone to refer to the frequent conflicts between principles and counter-principles, and the necessity of weighing and balancing them. Critics claim that weighing and balancing is inevitably influenced by judges' policy choices. Furthermore, Dworkin's distinction between principles (in the narrow sense of the term) and policies and his taking-rights-seriously thesis, requiring the formers' prevalence over the latter are of no help here. What is to be considered a principle and what a policy is by no means self-evident; this is a matter of interpretation - so the criticism goes - and hinges on a policy-based choice. A corresponding argument may be put forward in connection with limitation clauses (saving clauses), included in both international human-rights treaties and constitutional fundamental-rights provisions. For instance, the European Convention on Human Rights allows for limitations to other than absolute rights on enumerated grounds and adhering to the demands for necessity and proportionality. Balancing between a human or

\footnotetext{
${ }^{12}$ Charles Taylor, 'What is human agency? Human Agency and Language' in Charler Taylor, Philosophical papers I, (CUP 1985) 15.

${ }^{13}$ Koskenniemi, (n 11), 106.
} 
fundamental right and the ground for its limitation is akin to determining the respective weight of a principle and a counter-principle in an individual case. ${ }^{14}$

Again, I am ready to concede the partial validity of the critical argument: in spite of Alexy's, efforts to raise the rationality and controllability of the proportionality test, ${ }^{15}$ a decisionist residue inevitably afflicts always afflicts case-by-case weighing and balancing of principles and counterprinciples or principles and policies. Nonetheless, again the critical argument one-sidedly privileges the perlocutionary aspect and detaches individual legal speech acts from on-going legal discourse. The decisionist residue is controlled by subsequent legal speech acts, where the result of a particular weighing and balancing by a judge is appraised; speech acts by legal scholars, other judges and maybe even the legislator. Furthermore, the argument emphasizing the necessity of weighing and balancing leaves aside essential aspects in the functioning of legal principles. In adjudication, principles operate not only as discursively-formulated norms, as decision principles which have to be balanced with counter-principles in hard cases. They are also employed as source principles and interpretation principles. Furthermore, as general legal cultural principles they largely function through the tacit pre-understanding, the Vorverständnis, of legal actors. Such tacit knowledge is involved, say, every time when judges interpret policy-oriented statutes in the light of general legal principles.

When expressing doubts about the potential of legal principles to organize surface-level law, Thomas Wilhelmsson (2004) has invoked, not only the diversity of policy goals, but also ethical fragmentation permeating late modern culture; in his view, ethical fragmentation makes principlebased coherence, not just undesirable, but even unachievable. ${ }^{16}$ Dworkin's distinction between principles and policies respond to the problem created by the diversity of policy goals. Now the argument from ethical fragmentation seems to hit the very dimension of principles.

Value pluralism, ethical fragmentation, is not a recent phenomenon, but has been with us ever since the break-up of the unitary medieval worldview in early modern Europe under the impact of voyages of discovery and wars of religion. Yet, in analyzing the law's underpinning principles, one should take seriously not only the distinction between principles and instrumentalist policies but also another division within the scope of practical reason: that between ethics and morals. Ethics is about strong values, conceptions of the good life, as well as personal and collective identity definitions; in ethics, questions are posed from the perspective of an I or a We. In moral disputes, equal attention

\footnotetext{
${ }^{14}$ David Kennedy, A Critique of Adjudication (Harvard University Press 1997) 316; Koskenniemi, (n 11), 107.

${ }^{15}$ See Alexy, (n 1), as well as Alexy's contribution in this volume.

${ }^{16}$ Thomas Wilhelmsson, 'Yleiset opit ja pienet kertomukset ennakoitavuuden ja yhdenvertaisuuden näkökulmasta' Lakimies (2004) 199.
} 
must be paid to the standpoints of all concerned. Moral norms and judgements address real or potential conflicts in everyday human life; moral reasoning does not focus on what kind of life we wish to live and how we define our central values and identity; instead, moral questions are questions about how we should live together with other human beings who do not necessarily share our conceptions of the good life. ${ }^{17}$

Wilhelmsson is right in arguing that recent developments - globalization, migration, internet etc. - have further reinforced ethical fragmentation - the differentiation of identity-defining values and conceptions of the good. But it is imperative to note that in the distinction between ethics and morals, it is primarily the sphere of ethics that is affected. It may be that in respect of moral conceptions and norms, things have taken another path. It may be that instead of fragmentation, agreement on basic moral norms has actually expanded. National and international consensus reached has been codified in constitutional fundamental-rights provisions and international human-rights treaties, which have translated basic moral norms into legal language. However, expanded consensus has been accompanied by transformation of moral norms into increasingly abstract and general principles. As a result, emphasis in moral problems has shifted from justifiability of norms to their context-sensitive application. This is how Habermas, for instance, interprets development of postconventional morality. ${ }^{18}$

Fundamental and human rights, as well as related general legal principles of particular fields of law, are not so much focused on defining individual or collective values as on resolving conflicts between individuals or groups. This holds even for rights such as freedom of religion and conscience or freedom of expression. These rights do not purport to define identity-creating values from, as it were, above but to enable autonomous individual and collective choices. It behoves the normative premises of modern law to recede from the sphere of ethics, thus leaving ethics open for individual and collective value definitions. The task of the law only begins when divergent value orientations cause controversies between individuals or groups. But then we have already left the ethical I- or Weperspective behind us and entered the domain of moral reason.

In their criticism, CLS scholars, in line with the their colleagues in the Law and Economics camp, tend to recognize only one aspect of practical reason: instrumental reason allied with the voluntas of law. In the axiological dimension of values and goals, they detect merely the utilitarian, interest-based purposes which instrumentalistically-abridged practical reason is made to serve.

\footnotetext{
17 Jürgen Habermas,.'Towards a communication-concept of rational collective will-formation ' Ratio Juris 2(2) (1989) 144; Jürgen Habermas, 'Vom pragmatischen, ethischen und moralischen Gebrauch der praktischen Vernunft' in Jürgen Habermas, Erläuterungen zur Diskursethik (Suhrkamp 1991) 100.

18 Jürgen Habermas, Faktizität und Geltung (Suhrkamp 1996) 113.
} 
Identity-creating strong values, immune to strategically-determined compromise formation, fall outside the critical gaze. For radical critics, the very distinction between morals and ethics is a strategic choice, governed by instrumental reason.

\section{Policies and principles in EU law}

In a municipal legal order based on the normative ideas of a democratic Rechtsstaat - or constitutional democracy, as US scholars would put it - morally-laden principles, such as the constitutionally anchored principles of fundamental rights, democracy and the rule of law, lie in the core of the foundational legal "deep culture". This labels the legal order as a whole, rendering it a principleoriented character, in spite of the instrumental, policy-oriented character of most day-to-day legislation. Transnational law, such as EU law, is different. Typical of EU law is a policy orientation which extends to the level of constitutional law and which marks the legal order as a whole. State constitutions focus on the political and legal systems and leave substantive policy issues to ordinary legislation and daily politics in the framework established by the constitution. By contrast, the EU constitution has addressed even policy issues and includes, in addition to the framing political and juridical dimensions, also sectoral constitutions, such as the economic constitution - further differentiated into a micro- and macroeconomic constitution - the social constitution and the security constitution. The policy orientation is most conspicuous in the sectoral constitutions, but it has affected juridical constitutionalization as well. Such key principles of the juridical constitution as direct effect and supremacy are also justified by policy considerations; by the effective and uniform application of European law needed for which the establishment and functioning of the internal market. In the course of European constitutionalization, other objectives have been added, but this has not deprived European law of the policy emphasis. ${ }^{19}$

Accordingly, the substantive coherence which European law has manage to achieve has, to a large extent, been a result of policies rather than principles. All in all, building up sub-surface foundations for policy-oriented law, including constitutional law, has been an arduous process. Sectoral constitutions address policy issues which fall outside the typical materia constitutionis of state constitutions, and here Member State constitutional traditions can offer but meagre support for the development of a particular EU constitutional culture. In its central fields, EU law, comprising constitutional law too, has started cultural sedimentation from scratch: no national free movement

\footnotetext{
${ }^{19}$ See my analysis of the multi-dimensional and multi-temporal nature of the EU constitution in Kaarlo Tuori, European Constitutionalism (CUP 2015).
} 
law exists, and even national competition law is a relative newcomer. Furthermore, if a large consensus exists of the fundamental principles of a democratic Rechtsstaat, the theoretical and ideological justifications for policy issues which EU law addresses tend to be controversial. The legal cultural foundations of EU law are shakier than those of an established democratic Rechtsstaat.

In their sub-surface foundations, the juridical and political dimensions of the EU constitution partly differ from the general picture. General policy orientation affects the framing juridical and political constitutions, too, as is shown by the backdrop to direct effect and supremacy; i.e. central principles of the juridical constitution. Yet an important sub-field of the juridical and political constitutions exists which EU constitutional law shares with its national counterparts, where national constitutional traditions have been an important source, where EU law and Member State legal orders obviously share the same "deep culture" and where morally-laden principles temper the policy emphasis; namely, fundamental rights law.

In spite of the increasing significance of fundamental rights, EU law has retained its primarily teleological, policy-oriented character. Consequently, in conflicts of authority between European and national law - such as those involving the ECJ and the German constitutional court - often enough two different overall emphases confront each other: the policy orientation of European law and the principle orientation of national law. Through the reservations that national constitutional courts have attached to their acceptance of the supremacy of EU law, they defend the principle-based foundations of national law against the policy-motivated claims of authority raised by EU law.

EU law also provides us with an example of a legal order where the notion of legal principles possesses a doctrinal significance which should not be confused with the legal theoretical senses of the concept. The ECJ has accorded general principles of EU law a constitutional status, elevating them to the level of primary law, together with the Treaties. ${ }^{20}$ Moreover, some general principles, deemed foundational for the Union and its law, seem to occupy a privileged position vis-à-vis other primary law. In addition, some general principles accomplish a second-order justificatory function with regard to other, first-order principles. General legal principles manifest the central role of the ECJ in EU constitution-making perhaps at its most conspicuous. The Court has both established the normative contents of general principles and determined their position in European law.

Due to the case law origin of general principles, identifying them and defining their normative substance is shrouded in a veil of uncertainty. The Court has never produced even a tentative summary of what it considers to be constitutionally sanctified general principles. Direct effect and primacy of

\footnotetext{
${ }^{20}$ Case C-101/08 Audiolux and Others v Groupe Bruxelles Lambert and Others [2009] ECR I-9823, Para. 63.
} 
European law, which made Van Gend en Loos and Costa v Enel ${ }^{21}$ so renowned, certainly belong to them. However, in Van Gend en Loos and Costa v Enel the Court introduced not only these two principles positioning EC law in respect of Member State law. It also presented two pivotal metaprinciples with which it justified its audacious doctrinal innovations: effectiveness (effet utile) and uniformity (unity). These justificatory principles still today form an essential part of the Court's stock argumentative arsenal and must be included among the central elements of the juridical constitution. Effet utile in particular possesses international law roots. Yet, both principles address specific problems arising from the transnational character of EU law and the role of Member State authorities in its implementation. Practically all the major rulings reconfirming or expanding direct effect and primacy, or elaborating such auxiliary principles as the duty of consistent interpretation and state liability, have expressly invoked efficiency or uniformity. The Member State duty of sincere cooperation, which, diverging from effectiveness and uniformity, is explicitly enshrined in the Treaty (Art 4(3) TEU), is the third justificatory principle which the Court routinely invokes to buttress its case law promoting juridical constitutionalization.

In ECJ jurisprudence, effectiveness has served not only as a justifying meta-level principle for direct effect and primacy but as an independent basis for legal consequences as well. Effective implementation of European law has been argued to require appropriate national legal remedies and procedural guarantees and hence to justify incursions into Member State procedural autonomy. Furthermore, the Court has relied on effectiveness as a justification for criminal law sanctions outside the AFSJ, in the former Community pillar. ${ }^{22}$ In Takis Tridimas's words, the principle "requires the effective protection of Community rights and, more generally, the effective enforcement of Community law in national courts". ${ }^{23}$ The implications of effectiveness relate both to protection of individual rights and to effective enforcement of European law. In most cases, these two perspectives produce similar results: ever since Van Gend en Loos, the European juridical constitution has employed the vigilance of individuals over their rights as a means to secure enforcement of European law in national courts. In Lisbon, the constitutional legislator explicitly laid down that "Member States shall provide remedies sufficient to ensure effective legal protection in the fields covered by Union law" (Art. 19(1) TEU). ${ }^{24}$

The new provision in Art. 19(1) TEU also manifests the rule of law; yet another over-arching meta-level principle of the juridical constitution. This shows that in some contexts the principles of

\footnotetext{
${ }^{21}$ Case C-26/62 Van Gend en Loos [1963] ECR 3; Case C-6/64 Flaminio Costa v ENEL [1964] ECR 585.

22 The landmark case was C-176/03 Commission v Council ECR [2005] I-07879..

${ }^{23}$ Takis Tridimas, The General Principles of EU Law (2 ${ }^{\text {nd }}$ edn OUP 2006) 418.

${ }^{24}$ See on the principle of effectiveness Tridimas, ibid. 418.
} 
the rule of law and effectiveness work in the same direction. Yet, they may have contradictory implications as well. In juridical constitutionalization legal certainty has functioned as a counterprinciple restricting the expansion of direct effect and primacy, especially with regard to horizontal relations between private parties. It warrants threshold criteria for European norms which may obtain direct effect. It has also provided a justification for refusal by the ECJ to acknowledge horizontal direct effect for directives which have not been properly transposed into national law.

The rule of law principle made its first explicit entry into ECJ jurisprudence in Les Verts, where Court characterized the EEC with the innovative but not wholly felicitous expression 'community based on the rule of law'. ${ }^{25}$ The constitutional legislator only enshrined the principle in Treaty law in Amsterdam. ${ }^{26}$ In Les Verts, the Court identified the rule of law with the availability of remedies and procedures which ensure the conformity of both European and Member State measures with primary Union law. Moreover, the Court stressed the importance of access to justice by private parties to challenge the legality of an act affecting their Community rights or obligations. In its subsequent case law, the Court has relied on the rule of law both as an interpretive principle and as a source for more precise legal standards. ${ }^{27}$ Standards of judicial protection include the (sub-)principle of legal certainty, protection of legitimate expectations and the right to an effective remedy, at present guaranteed not only by Art. 19(1) TEU but Art. 47 CFREU as well. In recent jurisprudence, for instance in $\mathrm{Kadi}^{28}{ }^{28}$ the rule of law has been explicitly related to protection of fundamental rights (Para. 316). This link has added a substantive aspect to the principle of the rule of law.

As an overarching constitutional principle, the rule of law has its domicile in the juridical constitution, alongside effectiveness, uniformity and sincere cooperation. Through the framing function of the juridical constitution, the principle extends its influence to all the other constitutional dimensions.

Fundamental rights were also introduced into European law by the ECJ as general principles. In Maastricht the constitutional legislator expressly sanctified this constitution-making contribution by the Court. The Lisbon Treaty still retained the provision on fundamental rights as general principles of EU law (Art. 6(3) TEU). Yet, the Treaty also accorded the Charter of Fundamental Rights of the European Union the same legal value that the Treaties enjoy. Since Lisbon, the ECJ has shifted its

\footnotetext{
${ }^{25}$ Case C 294/83 Les Verts v Parliament [1986] ECR 1339.

${ }^{26}$ Art. 6(1) TEU referred to liberty, democracy, respect for human rights and the rule of law as principles which are common to the EU Member States and on which the Union is founded. A new Art. 7 TEU allowed for EU sanctions in the case of serious and persistent breach of the principles by a Member State, and Art. 49 defined them as criteria for accession to membership in the Union.

${ }^{27}$ Laurent Pech, "'A Union founded on the rule of law": Meaning and reality of the rule of law as a constitutional principle of EU law' (2010) 6 European Constitutional Law Review 359.

${ }^{28}$ Joined Cases C-402/05 P and C-415/05 P Kadi and Al Barakaat [2008] ECR I-6351.
} 
focus in fundamental rights protection on the Charter. However, general principles may still serve the ECJ as an additional normative resource for elaborating EU fundamental rights law, in particular on issues not tackled by the Charter.

As the preceding summary made clear, general principles of EU law include fundamental rights and the rule of law, which in the distinction between principles and policies fall within the former. Still, most of the general principles of EU law stem from policy considerations and give expression to the general policy-orientation of EU law. In conflicts of authority between Member State national law and EU law, national constitutional courts have invoked the inviolability of national constitutional identity. In a corresponding way, the ECJ keeps watch over the constitutional identity of the EU and, as a consequence, conflicts of authority turn into a clash between Union and Member State constitutional identity. It is not entirely clear how the ECJ defines the constitutional identity of the EU, but it seems to include at least the principles of direct effect and primacy, together with the justificatory second-order principles of efficacy and uniformity.

In relation to international law, a different definition may be adopted. Kadi involved a conflict of authority between EU law and international law. Here the ECJ asserted the constitutional identity of the EU against international law and included in this identity the protection of fundamental rights, i.e. the late-comer which has modified EU law's traditional policy-orientation.

\section{Conclusion}

Let us try to summarize. The polysemous nature of 'legal principles' may give rise to confusion, especially if a particular meaning is transferred to a foreign context. Decision principles, examined by Dworkin and Alexy, are directly applicable, surface-level norms, constituting a type of norms complementary to legal rules. By contrast, general legal principles, summarizing normative contents of a branch of law or a legal order as a whole, are inhabitants of the law's sub-surface, legal cultural levels. Varieties of legal principles exist, all with a particular location in the multi-layered structure of a legal order and a particular role in the functioning of the law.

The distinction between morals-related principles and policies aiming at specific societal goals was central for Dworkin's taking-rights-seriously thesis but downplayed by Alexy. The distinction, which can be extended not only to surface-level principle-like norms but also to general legal principles located in the legal cultural sub-structure, should be retained for the sake of normative 
argumentation; for letting fundamental rights perform their power-restrictive function and for providing the law with doctrinal means in its self-defence against excessive instrumentalization. The distinction also facilitates understanding the backdrop to conflicts of authority between EU and Member State law: the clash between policy- and principle-orientation. The more radical criticism, claiming that principles collapse into policies and that the very division is policy-based, too, can also be shown to falter.

'Legal principle' is not only a legal theoretical but also a doctrinal concept, tied to a particular legal order. An examination of the doctrine of the general principles of EU law offers an example of a doctrinal discussion where legal theoretical insights into the varieties of legal principle offer but little guidance. 